\title{
How to Explain Popular to a Dead Hare
}

\section{OTT KARULIN}

\begin{abstract}
In this article the popular is defined with the tools of field theory by Pierre Bourdieu, that is as production with high degree of outer-field economic capital (measured with the number of visits per production). It is also claimed that on some conditions these productions do not lower the degree of autonomy of the field since theatre manages to convert the economic capital to symbolic capital (nominations for annual awards give evidence of the latter). Such a production is called the Full Game.

Based on the comparable data of new productions made in Estonia from 2010 to 2015 (1199 in total) the article will introduce a possible methodology of how to calculate the popular in theatre that considers both the number of visits per production in a year and the use of seating capacity. Following that methodology, there were only sixty-one productions during the chosen period that could be titled popular in a sense that they have a very high degree of outer-field success (these productions are visited 2,4 times more often than the average number of visits per production in one calendar year and have the attendance rate of $95 \%$ and higher). Taking into account also the inner-field specific consecration (whether they have been nominated for annual theatre awards), only twenty-three popular productions - among them just one comedy, one musical and one operetta - remain in the list of what I have called the Full Game. That is two per cent of all the new productions of the respective time period.

The list of Full Games suggests that the specific theatre, where the production is performed plays a significant role for a production to become popular. Only four theatres have had more than one Full Game in 2010-15 in Estonia and two of them - Theatre NO99 and Tallinn City Theatre - are used as case studies to find possible strategies of being popular without loosing specific consecration.
\end{abstract}

\section{KEYWORDS}

Theatre systems; Estonian theatre; Pierre Bourdieu; Economic and symbolic capital; Audience; Theatre NO99; Tallinn City Theatre; Full game. 



\section{How to Explain Popular to a Dead Hare}

In a production of Theatre NO99 entitled How to Explain Pictures to a Dead Hare (2009) there is a scene in which giant rabbits (people in respective fullsize costumes) visit an art gallery. They look at the pictures on the wall and then read the paper-guide in their paws. They look at the pictures again, they look at each other in confusion, they read the guide again until they are confronted with the last piece of the exhibition - a man pressed against the wall by a plank, his torso resting on the latter. This production, an obvious reference to the sametitled performance by Joseph Beuys (1965), asks at what moment making an artwork understandable to a broader public lowers the artistic quality of that artwork.

Popular culture is often seen as something that is appreciated by many and therefore considered to be artistically less challenging. In this article, the popular is defined with the help of Pierre Bourdieu's field theory, that is to say: as a production with a high degree of outer-field economic capital (measured by the number of visits per production). ${ }^{1}$ It is also claimed that in some conditions these productions do not lower the degree of autonomy of the field since the

${ }^{1}$ Besides the number of visits the ticket income revenue could also measure the economic capital of a production and ideally these two should both be considered (as was done in my dissertation) but since in Estonia ticket prices do not vary too much in theatres only the number of visits has been taken into account in this paper. 
theatre manages to convert the economic capital into symbolic capital (reviews of productions give evidence of the latter). Such a production is called a Full Game. The theoretical discussion will fill the first part of the article, followed by a statistical analysis of the number of visits and annual awards in order to find the productions that have both a high degree of economic capital (that is the outerfield success) and symbolic capital (the inner-field specific consecration). In the latter part of this article, some case studies will be discussed.

\section{INNER- AND OUTER-FIELD SUCCESS}

First, a short overview of Pierre Bourdieu's Field Theory, focusing on the autonomy of the field and the double-hierarchization - the inner-field specific consecration and the outer-field success - of the fields of cultural production (of which the theatre field is an example), will be given. Later, the concept of how to describe the mechanisms of preserving the autonomy of the fields of cultural production is introduced. ${ }^{2}$

According to Bourdieu, there are three main special criteria distinctive to the fields of cultural production: (a) the high degree of the autonomy of the field, (b) the denial of economy and (c) eternal opposition between the dominating "art for arts' sake" and the dominated mass production. Bourdieu argues that it is characteristic to the fields of cultural production that "the more autonomous it is, i.e. the more completely it fulfils its own logic as a field, the more it tends to suspend or reverse the dominant principle of hierarchization; but also that, whatever its degree of independence, it continues to be affected by the laws of the field which encompasses it, those of economic and political profit." ${ }^{3}$ Thus, Bourdieu speaks of double-hierarchization: on the one hand "[t]he heteronomous principle of hierarchization, which would reign unchallenged if, losing all autonomy, literary and artistic field were to disappear (so that writers and artists became subject to the ordinary laws prevailing in the field of power, and more

\footnotetext{
2 The theoretical chapter is based on the author's dissertation, see: Karulin 2013.

${ }^{3}$ Bourdieu 1993, 38-39.
} 
generally in the economic field)." This principle can be said to be evident in success. On the other hand, Bourdieu defines "[t]he autonomous principle of hierarchization, which would reign unchallenged if the field of challenge were to achieve total autonomy with respect to the laws of the market,"5 evident in the degree of specific consecration. Because of that double-hierarchization, the degree of autonomy of the fields of cultural production is always changing: "[T]he greater the autonomy of a field, the stronger the consecrated positions within the field; or, the other way around, the weaker the position of the field is in relation to the environment in terms of autonomy, the stronger are the marketoriented positions within the field." The previous does not mean that Bourdieu denies any striving to economic success in the fields of cultural production, but he does claim that economic success will always challenge the autonomy of the field $^{7}$, so that any action in the fields of cultural production is followed by the argument about the transformation costs between the cultural and economic capital since in the fields of cultural production, the economic success of the outer-field might not be converted into symbolic capital.

Hans van Maanen has challenged Bourdieu, stating that "it might well be true that specific symbolic capital (artistic prestige) and a high degree of autonomy do go hand in hand, but the combination does not fully exclude the attracting of economic capital, because the production linked to them does not necessarily take place in the sub-field of restricted production." ${ }^{\prime 8}$ In other words: economic success can sometimes raise the amount of the symbolic capital of an agent if the agent is in a dominant position in the field and has the power to change the structure of the field.

For Bourdieu, the agents on the fields of cultural production promoting the notion of 'art for art's sake' are activated every time the structure of the field leans too much towards commercial art. The opposition between "art for arts'

\footnotetext{
${ }^{4}$ Ibid.

5 lbid.

6 van Maanen 2009, 65.

7 Bourdieu 1998, 57.

8 van Maanen 2009, 67.
} 
sake" and mass-production has often been challenged: "As a result of the greater social mobility of people and technological development of media and means of dissemination, the mechanisms of autonomization have been weakened and thus the distinction between high and low culture has become irrelevant." ${ }^{\prime 9}$ One has to agree that in post-modern society the distinction between high and low culture is no longer that clear, but that does not automatically mean the disappearance of autonomous fields of cultural production. If we agree with Bourdieu that cultural and economic capital are opposites and that art aiming to attain only the latter is commercial, we also have to agree that in any field (of cultural production) there exist, side by side, agents defending the orthodoxy and newcomers that wish to alter the structure of the field and thus break with the heterodoxy. ${ }^{10}$ This orthodoxy also shows what the specific consecration consists of and what are the transformation costs between economic and cultural capital.

Before moving on, questions about the position of critics and audiences should be approached. For Bourdieu, the position of audiences is rather heteronomous, or, as van Maanen has put it: "As ticket-buyers they are part of the economic field; as students they are part of the educational field, as decision makers they can be part of the field of power." ${ }^{11}$ Still, in all these cases, audiences are outer-field agents. Critics on the other hand take a double position: they are part of a theatre process (since their feedback, which could be a reflection of the audiences' perception, might influence the future artistic choices of an artist), but at the same time, they are always looking in from the outside (as model viewers who mediate the artistic intentions to the outer-field agents, that is to the potential audiences), thus indicating the presence of the field. ${ }^{12}$ Therefore, critics should be seen as a mediating field between the fields of theatre and audiences and therefore reviews are, on one side, the mediators of inner-

\footnotetext{
9 van den Hoogen 2010, 236.

${ }^{10}$ van Maanen 2009, 61.

${ }^{11}$ Ibid, p. 130.

${ }^{12}$ Ibid, p. 131.
} 
field criteria to the audiences and at the same time, critics guard the agents acting according to these inner-field rules.

This, of course, influences a theatre (as an institutional agent) making its artistic choices in the field of theatre. Each theatre would ideally make artistic choices based only on their own artistic value system (that might be written down in strategic documents), that is autonomously, but as Bourdieu has stressed, the fields of cultural production are always influenced by political and economic fields. ${ }^{13}$ Thus, the artistic choices of a theatre are influenced firstly by the purposes of the state's (cultural) policy, since the latter "collects the entirety of the material and symbolic resources" ${ }^{14}$ and organizes the functioning of different fields, either through financial or juridical intervention, which in the theatre field is evident in legislation, subsidy system, strategies of the Ministry of Culture, etc. Secondly, the artistic choices of a theatre are influenced by the tastes of audiences that become evident in their decisions to visit a production, which is seen in the statistics of ticket sales. So, a theatre always has to make a compromise with its artistic value system when taking into account the tastes of audiences and that compromise always means a lower degree of autonomy.

In addition, the artistic value system of a theatre is influenced by the tastes of the individuals related to that theatre. These can be found in published interviews and in the protocols of the meetings of the artistic board. It is between the tastes of the theatre workers (especially the management) and the purposes of the state's (cultural) policy that a theatre has to make the second compromise and as an outcome of the two compromises - the first between the theatre's artistic value system and the tastes of audiences and the second between the tastes of theatre workers and the purposes of the state's (cultural) policy - the final artistic choice is made.

In other words: theatres have to ask themselves with every production how much they can increase the degree of outer-field success and therefore lose in the degree of inner-field specific consecration without the field losing its auton-

\footnotetext{
${ }^{13}$ Bourdieu 1993, 39.

${ }^{14}$ Bourdieu 2003, 60.
} 
omy. Such a production that has both a high degree of success and specific consecration, since it manages to convert partly and/or temporarily the outerfield success into inner-field specific consecration, is here called a Full Game ${ }^{15}$.

\section{SEARCH FOR FULL GAMES}

My dissertation ${ }^{16}$ analysed the repertoire of one theatre - the Rakvere Theatre ${ }^{17}$ - between 1985 and 2009. During the period, the theatre staged 201 new productions, of which only five fulfilled the criteria of the Full Game, meaning that the Rakvere Theatre reached its goal of achieving a Full Game with every fortieth production, resulting in Full Games amounting to only 2,5\% of all productions. To test whether this ratio is characteristic only for the Rakvere Theatre or might be considered representative for the whole Estonian theatre field, and in addition to further develop the methodology of the research, comparable data of productions made in Estonia from 2010 to 2015 were analysed for this article. ${ }^{18}$

${ }^{15}$ The choice of the term Full Game lies heavily in the context of the author's dissertation based on productions of Rakvere Theatre. One of these productions, corresponding to the criteria of Full Game, is a stage-adaptation of a well-known movie "Full Monty" translated into Estonian as Täismäng (where täis means full and mäng means game).

${ }^{16}$ Karulin 2013.

${ }^{17}$ Rakvere Theatre, established in 1940 , is a repertoire-theatre in Rakvere, a city with 15000 inhabitants, one hundred kilometres east from the capital of Estonia. Rakvere Theatre is a state-owned and state-funded theatre with three venues: a big hall with 411 seats, a small hall with 118 seats and a project-room with 40 seats. They have, on average, six to eight new productions each season and give around 380 performances in one calendar year, of which about $40 \%$ go on tour in Estonia, and have an annual audience of about 70000 .

${ }^{18}$ Although the Estonian Theatre Agency has collected theatre statistics since 2004 they have only published the data electronically since 2010, which also marks the starting point of the analysis for this article. 


\begin{tabular}{|c|c|c|c|c|}
\hline Year & $\begin{array}{l}\text { The number of } \\
\text { productions in } \\
\text { repertoire }\end{array}$ & $\begin{array}{l}\text { Of those new } \\
\text { productions }\end{array}$ & $\begin{array}{c}\text { The number of } \\
\text { total visits }\end{array}$ & $\begin{array}{c}\text { The average } \\
\text { number of visits } \\
\text { per production } \\
\text { (and \% of these } \\
\text { out of total } \\
\text { visits) }\end{array}$ \\
\hline 2010 & 419 & 182 & 907243 & $2165(0,24 \%)$ \\
\hline 2011 & 463 & 191 & 1008253 & $2178(0,22 \%)$ \\
\hline 2012 & 486 & 203 & 1142918 & $2352(0,21 \%)$ \\
\hline 2013 & 496 & 192 & 1091139 & $2200(0,20 \%)$ \\
\hline 2014 & 525 & 206 & 1050247 & $2000(0,19 \%)$ \\
\hline 2015 & 567 & 225 & 1164784 & $2054(0,18 \%)$ \\
\hline Average & & & & $2153(0,20 \%)$ \\
\hline
\end{tabular}

Table 1: The overall data of Estonian theatre productions and the use of seating capacity from 2010 to 2015 . Source: www.teater.ee/stat/main

As shown in Table 1, between 419 and 567 productions were in the repertoire of Estonian theatres over a calendar year, and 1199 new productions were staged during the chosen time-period of six years. The number of visits vary from a little over 900000 to more than 1,1 million visits per year, meaning that one production receives an average of 2153 visits per year (total number of visits over a year divided by the number of productions in repertoire in the same year). One could argue that the number of visits per production during its run may be a more valid measuring tool than the visits in a calendar year, but my analysis proves that even if a production is premièred in late autumn, it will still be present in the list of productions with a number of visits greater than the average during the next calendar year. In other words: these productions have an equal or a greater degree of outer-field success than productions in Estonia have on average, and can thus be called successful. Following Bourdieu, one can easily state that an equal or slightly greater than average degree of outerfield success does not yet jeopardize the autonomy of a theatre field as a field of cultural production since it does not challenge the orthodoxy of the field as described earlier. Table 2 shows that on average one third of the productions in repertoire in Estonia receive more visits than the annual average and that these productions combined receive more than $70 \%$ of total theatre visits per year. 


\begin{tabular}{|c|c|c|c|c|c|}
\hline Year & $\begin{array}{l}\text { The number (and } \\
\% \text { ) of succesful } \\
\text { productions in } \\
\text { repertoire }\end{array}$ & $\begin{array}{c}\text { The number (and } \\
\% \text { ) of vistis of } \\
\text { succesful } \\
\text { productions out } \\
\text { of total visits }\end{array}$ & $\begin{array}{c}\text { The average } \\
\text { number of visits } \\
\text { of succesful } \\
\text { productions per } \\
\text { production (and } \\
\% \text { of these out } \\
\text { of total visits) }\end{array}$ & $\begin{array}{l}\text { The number (and } \\
\% \text { ) of popular } \\
\text { productions in } \\
\text { repertoire }\end{array}$ & $\begin{array}{l}\text { The number (and } \\
\% \text { ) of vistis of } \\
\text { popular } \\
\text { productions out } \\
\text { of total visits }\end{array}$ \\
\hline 2010 & $114(27 \%)$ & $639421(70 \%)$ & $5609(0,62 \%)$ & $44(11 \%)$ & $397761(44 \%)$ \\
\hline 2011 & $137(30 \%)$ & 727307 (72\%) & $5309(0,53 \%)$ & $33(7 \%)$ & $367335(36 \%)$ \\
\hline 2012 & $143(29 \%)$ & $840818(74 \%)$ & $5880(0,51 \%)$ & $45(9 \%)$ & $497522(44 \%)$ \\
\hline 2013 & $153(31 \%)$ & $799282(73 \%)$ & $5224(0,48 \%)$ & $52(10 \%)$ & $459030(42 \%)$ \\
\hline 2014 & $160(30 \%)$ & $754680(72 \%)$ & $4717(0,45 \%)$ & $32(6 \%)$ & $352157(34 \%)$ \\
\hline 2015 & $182(32 \%)$ & $841865(72 \%)$ & $4600(0,39 \%)$ & $60(11 \%)$ & $454701(39 \%)$ \\
\hline Average & & & $5178(0,50 \%)$ & & \\
\hline
\end{tabular}

Table 2: The overall data of successful and popular productions in Estonia from 2010 to 2015. The proportions of popular productions by target group and genre are shown later in Figure 1 and Figure 2 respectively. Source: www.teater.ee/stat/main

In order to be able to find, in the first place, productions that might have the degree of an outer-field success capable of threatening the autonomy of the field (as is argued by Bourdieu) and called from here on popular, and secondly productions managing to temporarily convert the outer-field success to innerfield specific consecration (as is seen possible in this article), the stakes have to be higher. Column four in Table 2 shows that the average number of visits of productions with greater than average economic capital in the bourdieusian sense in a calendar year (visits gathered by all successful productions divided by the number of successful productions) amounts to 5178 visits per production.

As is evident form the table, only 6 to $11 \%$ of the theatre productions manage to receive more visits - and an equal or higher degree of outer-field success - than the average successful productions. These are the popular productions (and thus titled), collecting more than one third of all theatre-visits in a year. The statistical analysis also suggests that on average a production has to attain more than half a per cent of total theatre-visits in at least one calendar year to fulfil the criteria of popular. Thus, one could skip the afore-described time-consuming process of finding the number of visits per production in a calendar year simply by calculating the half of per cent of total visits (by multiplying that number with 0,005). 
One might also ask if this process should be repeated for the third time and whether the 2,4-fold greater degree of outer-field success is large enough for a production to threaten the autonomy of the theatre field. Looking at the list of productions that have received a number of visits equal or greater than the average popular productions in a calendar year (the number of such productions varies from seven to twenty-two in the period analysed), it is noticeable that $65 \%$ of these productions are either comedies, musicals or operettas - all of which are considered commercial genres more influenced by the field of mass production and thus not part of an autonomous theatre field as defined by Bourdieu.

Another question to ask here is whether all productions receiving more than half a per cent of total visits in at least one calendar year, necessarily fulfil the criteria of popular. To answer that question another measuring tool has to be introduced - the use of seating capacity. Taking into account only the number of visits per production favours productions that are performed in bigger venues (a production in a half-empty hall with four hundred seats still has more visitors than a sold-out performance in a venue with one hundred seats). Therefore, if we list only productions with the use of seating capacity of $95 \%$ or higher (at least in one calendar year between 2010 to 2015; only counting productions that are present in the list of popular productions of at least one calendar year), we end up with sixty one productions - that is five per cent of the total number of new productions in 2010-15.

According to Bourdieu, these productions should follow the logic of mass production and thus threaten the autonomy of the theatre field. Figure 1 demonstrates that most of the popular productions in Estonia from 2010 to 2015 were meant for adults $(62 \%)$, which is no surprise as it is the main target group ${ }^{19}$, although the ratio in popular productions is a bit lower than in the overall repertoire

${ }^{19}$ The target group of a production is chosen in collaboration with a theatre submitting the statistical data to the Estonian Theatre Agency and the latter. Therefore, this criteria is somewhat subjective - although the experts of the agency do try to structure the choices made by theatres - and can lead to strategic choices by a theatre, such as marking musicals as productions for youth to have something to show in this target group. 
(77\%). The ratio of productions aimed at a youth audience (17 to $20 \mathrm{yrs}$.) among the popular productions is twice as large as in the overall repertoire since most of the productions for youth tend to be musicals and thus popular.

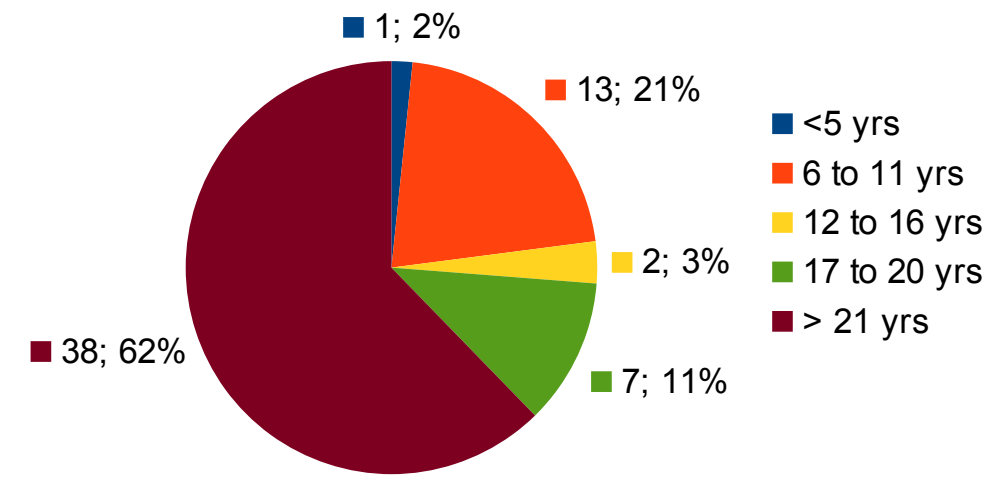

Figure 1: Target groups of popular productions (number of productions; per cent of all popular productions).

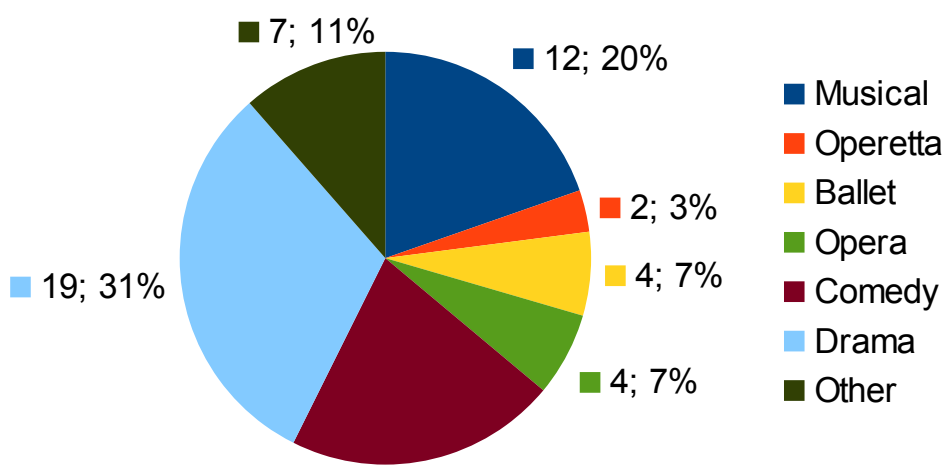

- $13 ; 21 \%$

Figure 2: Genres of popular productions (number of productions; per cent of all popular productions).

The division by genre (see Figure 2) is far more telling: musicals (20\%) and comedies $(21 \%)$ do not have the biggest ratio in popular productions, being shadowed by dramas (31\%). This suggests that even though a production fulfils the category of popular, it is not necessarily artistically less demanding as is claimed by Bourdieu. To further prove this conclusion, the inner-field specific consecration of popular productions should be taken into account. The latter could, for example, be measured in nominations and awards given to those affiliated with the production. In the case of Estonia this means the annual theatre awards given in many categories (best director, set designer, 
actor/actress, supporting actor/actress; best dance / ballet / music / performance art production, etc. by the jury consisting of both critics and creators) ${ }^{20}$

Taking into account only productions that have been nominated at least once and therefore have a greater than average degree of inner-field consecration, only twenty-three popular productions - among them just one comedy, one musical and one operetta - remain in the list of what I have called the Full Game (see the list in Appendix 1). That is two per cent of all the new productions of the respective time period, so half a per cent less than was the case with Rakvere Theatre as presented in my dissertation. ${ }^{21}$

The list of Full Games also suggests that the specific theatre, where the production is performed, plays a significant role for a production to become popular (the latter is also true for popular productions of which more than half were performed in three theatres and the other half in eleven theatres). Only four theatres have had more than one Full Game in 2010-15: the Estonian National Opera (seven Full Games), Theatre NO99 (six), the Tallinn City Theatre (four) and Vanemuine Theatre (three). It should be noted that the National Opera is in a somewhat different position since the same ballet or opera could be nominated in more than one year, depending on when a dancer/singer had their opening night in this production. Vanemuine Theatre is the only theatre in Estonia that stages drama, dance, and musical productions, and has one of each in the list of Full Games. Therefore, the comparison of these two with other theatres is difficult and will be left for later analysis. Theatre NO99 and Tallinn City Theatre are in that sense much easier to compare, although they represent the far ends of a spectrum regarding both aesthetic choices and functions that they as theatre aim to fulfil as is shown in the following.

${ }^{20}$ The list of nominees and award winners can be found here: http://teatriliit.ee/ auhinnad.

${ }^{21}$ For in-depth knowledge, one should also analyse the critical response a production gets, but this is too time-consuming with large numbers of productions. I did take the in-depth approach in my dissertation and concluded that Full Games, besides gathering more visits, also get a more vivid, greater in amount and often controversial feedback. Starting with the reviews and not with the awards (not all theatres get them) could also be the reason why Rakvere Theatre had half a per cent more Full Games. 


\section{CASE STUDY: THEATRE NO99 AND TALLINN CITY THEATRE}

Theatre NO99 was created in place of a bankrupt state-owned comedy-theatre in 2005 and is run by the stage directors Ene-Liis Semper and Tiit Ojasoo. The company's repertoire is characterized by political activism and post-dramatic productions. Theatre NO99 has its own venue with little less than two hundred seats, but it has also performed in bigger venues elsewhere in Tallinn. The name of the theatre refers to its proclaimed aim of staging a limited number of ninety-nine productions (the first one was numbered ninety-nine. The season of 2016-17 was opened with a production numbered thirty-nine, so this theatre should come to its natural end in five or six years). Theatre NO99 also tours outside the country more frequently than other Estonian theatres, having performed mainly in German-speaking countries. What is also remarkable is that all of their six popular productions are also Full Games of which five are in the top eleven of Full Games consisting of productions with at least two nominations (see Appendix 1).

Tallinn City Theatre was established in 1965 as Estonian Youth Theatre, but changed its name in 1994 when the municipality of Tallinn started subsidizing the theatre together with the state. From 1992 until today, the artistic leader of the theatre is Elmo Nüganen, perhaps one of the most awarded Estonian directors (besides Semper and Ojasoo of NO99). Tallinn City Theatre mostly stages dramatic plays of psychological realism. The theatre has its own building complex with multiple small venues that seat 87 to 182 spectators; they also have an open-air stage with more than 300 seats. This theatre has had ten popular productions (plus one co-production with another theatre) in 2010-15, four of which fulfil the category of Full Games. Three of their Full Games are in the top eleven (see Appendix 1).

It is already obvious from the short descriptions that Theatre NO99 and Tallinn City Theatre are very different from each other, especially in their artistic choices: the post-dramatic productions of Theatre NO99 are often political commentaries, whereas Tallinn City Theatre is cherished for its productions of (classical) drama with an emphasis on acting in the tradition of Stanislavski. To 
support this argument with statistical data, a word-count analysis of the reviews written about the Full Game productions in the top eleven of both theatres was conducted, using an open access web-tool that lists all words in texts fed to the tool by the number of their occurrence. ${ }^{22}$ The selection consisted of eleven reviews of the Full Games of Theatre NO99 for their productions Assembly of Unified Estonia, The Rise and Fall of Estonia, Three Kingdoms and How to Explain Pictures to a Dead Hare (remember the scene with the confused big rabbits at the art gallery $)^{23}$ and nine reviews of Tallinn City Theatre's Full Games, I Loved a German, The Coast of Utopia: Voyage and Longing. ${ }^{24}$ Considering that only some productions - no doubt, Full Games among them - get reviewed in the culture weekly paper Sirp as well as in both daily-papers (Postimees and Eesti Päevaleht), and other weekly papers (Eesti Ekspress, Maaleht - all the reviews in the mentioned papers were included in this analysis), the number of reviews analysed is close if not equal to the number of reviews published about these productions.

${ }^{22}$ For this analysis http://www.wordclouds.com/ was used. After the initial list of words was generated by the tool, the editing of this list followed, taking into account different forms of the same words (e.g. in singular or plural, cases, etc.). After that, clusters of words by topic were created.

${ }^{23}$ See: Laasik 2011; Allik 2010 and 2011; Prints 2009; Kolk 2009; Tõnson 2010; Niineste 2011; Oidsalu 2011; Karulin 2011; Laks 2010; Laks and Kressa 2010.

${ }^{24}$ See: Laasik 2009; Kaus 2010; Herkül 2014; Kolk 2013; Mikomägi 2014; Johannes 2013; Purje 2014; Veidemann 2009 and 2014. 


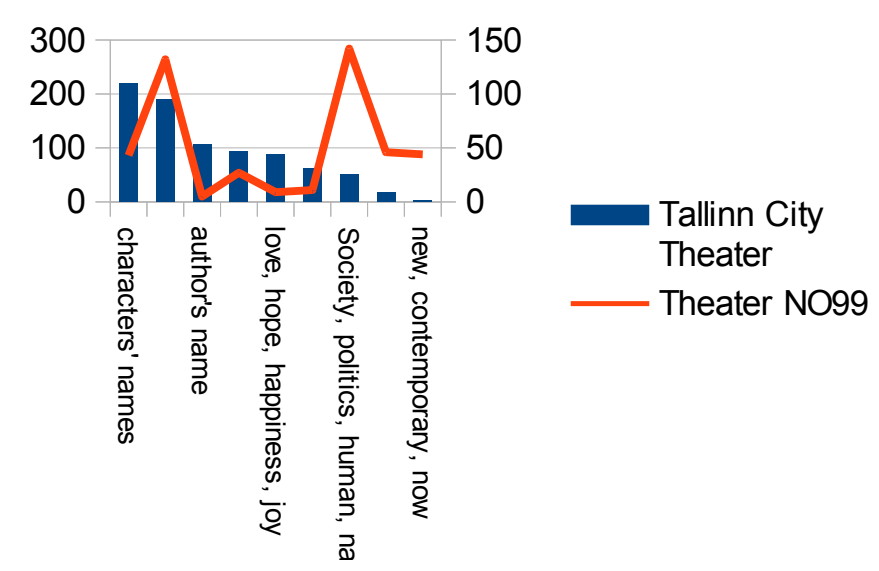

Figure 3: Clusters of words represented in reviews of the productions of Tallinn City Theatre and Theatre NO99.

Figure 3 lists clusters of words that appear frequently in reviews or where the difference between two theatres is significant. Only one cluster - name of director(s) and actors - is equally prominent in the reviews of both the productions of Tallinn City Theatre and Theatre NO99. In the case of Tallinn City Theatre, the names of the characters of the play are most prominently mentioned in reviews, as is the name of a playwright and the words connected to a written play (such as "story", "role") are present multiple times more often than in the case of Theatre NO99 (106 and five; 93 and 27 respectively). As stated before, Tallinn City Theatre is commonly praised for its dramatic work, often staging works by classical authors (such as Estonian A. H. Tammsaare's I Loved a German) or modern classics like Tom Stoppard's Coast of Utopia: Voyage (Longing by William Boyd is a dramatization of short stories by Anton Chekhov). As might be expected, these plays raise comments in reviews about what can be defined as core emotions of existence (like love, hope, etc.) and life itself. Such words are almost completely absent from the reviews of the productions of Theatre NO99, which concentrates mostly on post-dramatic work where the text is authored by a group of people (actors included), addressing social and political issues. Thus, word-clusters of "society, politics, human, nation, us, I" and "new, contemporary, now" as well as the word "spectator" dominate in reviews of their productions but are scarcely present in the feedback given to Tallinn City Theatre. 


\section{QUESTIONS FOR FURTHER RESEARCH}

Although the outcome of the analysis of feedback through word-clusters might seem void (there are no common categories which could be seen as relevant for a production to become a Full Game), it does, since there are not any common categories, suggest that the theatre where the production is performed might play an even more important role in creating Full Games than the production itself. Both Tallinn City Theatre and Theatre NO99 have a strong and differentiable image both among theatre-goers and critics, thus having both outerfield success and inner-field specific consecration. It was argued above that, contrary to Bourdieu's claim, it is possible for a theatre to convert the outer-field success to inner-field specific consecration. The analysis done clearly supports the argument that there is a connection between these two. It is also plausible that, in fact, a higher degree of inner-field specific consecration has a positive effect on the outer-field success, that is: nominations and awards attract more visits (out of the popular productions in Estonia in 2010-15 one third were Full Games) but in order to better understand if the outer-field success has an influence on the inner-field specific consecration, the chosen methodology is not sufficient on its own and should be supported with more qualitative data, e.g. interviews with critics and members of award-committees. In other words, coming back to the scene described in the beginning of this article: it is very plausible that the giant rabbits in How to Explain Pictures to a Dead Hare came to visit the art gallery after the exhibition had won a prestigious award but one cannot say how many rabbits should visit the exhibition for it to be considered for an award. Or, in that matter, if there is a number of visiting rabbits too much for an exhibition to become too popular to be considered for an award.

Also, the methodology introduced in this article should be implemented on statistics of other countries besides Estonia to verify the results: that popular productions should receive at least half a per cent of the total theatre-visits in a calendar year to be considered popular, that popular productions with the use of a seating capacity of $95 \%$ and higher make five per cent and Full Games only two per cent of all productions in the repertoire. Finally, the word-cluster method 
is of great use when comparing different theatres based on professional feedback given to their productions as it leads to tangible quantitative results, but it probably will not present common categories that could be defined as characteristic of Full Games.

\section{APPENDIX 1. FULL GAMES IN ESTONIA 2010-15.}

\begin{tabular}{|c|c|c|c|c|c|}
\hline Theatre & Author(s) & Title & Genre & Nominations & Awards \\
\hline Theater NO99 & Group work & Assembly of Unified Estonia & drama & 5 & 1 \\
\hline Theater N099 & Group work & The Rise and Fall of Estonia & drama & 5 & 0 \\
\hline Estonian National Opera & Kenneth MacMillan / Jules Massenet & Manon & ballet & 4 & 3 \\
\hline Theater NO99 & Simon Stephens & Three Kingdoms & drama & 4 & 2 \\
\hline Theater NO99 & Vaiko Eplik, Jakob Juhkam & Savisaar & other & 4 & 1 \\
\hline Estonian National Opera & Charles Gounod & Faust & opera & 3 & 1 \\
\hline Tallinna City Theater & A.H.Tammsaare, Elmo Nüganen & I Loved A German & drama & 3 & 1 \\
\hline Theater N099 & Group work & How to Explain Pictures to a Dead Hare & drama & 3 & 0 \\
\hline Tallinna City Theater & Tom Stoppard & Coast of Utopia. Voyage & drama & 3 & 0 \\
\hline Tallinna City Theater & William Boyd & Longing & drama & 2 & 1 \\
\hline Estonian National Opera & Gyula Harangozó & Snow White and the Seven Dwarves & ballet & 2 & 0 \\
\hline Estonian National Opera & Tiit Härm & Swan Lake & ballet & 1 & 1 \\
\hline Estonian National Opera & Giuseppe Verdi & Rigoletto & opera & 1 & 1 \\
\hline Eesti Draamateater & Tracy Letts & August. Osage County & comedy & 1 & 1 \\
\hline Puppet Theatre & Jevgeni Ibragimov & The ABC of Puppetry & other & 1 & 1 \\
\hline Theater N099 & Group work & My Wife Got Angry & drama & 1 & 1 \\
\hline Von Krahl Theater & Veljo Tormis & The Songs of Estonian Men & other & 1 & 1 \\
\hline Estonian National Opera & Ben Stevenson & The Nutcracker & ballet & 1 & 0 \\
\hline Estonian National Opera & Imre Kálmán & Silva & operetta & 1 & 0 \\
\hline Tallinna City Theater & Ferenc Molnár & The Paul Street Boys & drama & 1 & 0 \\
\hline Vanemuine & Robert James Waller & The Bridges of Madison County & drama & 1 & 0 \\
\hline Vanemuine & Georges Bizet & Carmen & opera & 1 & 0 \\
\hline Vanemuine & Andrew Lloyd Webber & The Phantom of the Opera & musical & 1 & 0 \\
\hline
\end{tabular}




\section{References}

Allik, Jaak. 2010. "Parteipilet peaks kõigil taskus olema." Maaleht 13 May.

Allik, Jaak. 2011. "Lugu oma õnne õgivast rahvast.” Postimees 26 March.

Bourdieu, Pierre. 1993. The Field of Cultural Production. Essays on Art and Literature. Cambridge: Polity Press.

Bourdieu, Pierre. 1998. On Television. New York: The New Press.

Bourdieu, Pierre. 2003. Praktilised põhjused. Teoteooriast. Tallinn: Tänapäev.

Herkül, Kadi. 2014. "Pantalone pisaraid ei usu." kultuur.err.ee 4 June.

van den Hoogen, Quirijn L. Performing arts and the city. Dutch municipal cultural policy in the Brave New World of evidence-based policy. Groningen: Rijksuniversiteit Groningen.

Johannes, Maris. 2013. "Tunnid Stoppardi meistriklassis.” Sirp 4 April.

Karulin, Ott. 2011. "Sõin ja jõin seal minagi." Sirp 1 April.

Karulin, Ott. 2013. Rakvere Teater "täismängude" otsinguil aastatel 1985-2009.

Tartu: Tartu University Press.

Kaus, Jan. 2010. "Eluvõitluse tühjus ime umber." Sirp 7 January.

Kolk, Madis. 2009. "Kas loomastumine või lepitus?" Sirp 20 March.

Kolk, Madis. 2013. "Tom Stoppardi üldinimlik intellektualism.” Sirp 4 April.

Laasik, Andres. 2009. "Suur sakslase- armastus täidab tühja ruumi." Eesti Päevaleht 14 December.

Laasik, Andres. 2011. "Kolm kuningriiki näitasid traagelniite.” Eesti Päevaleht 22 September.

Laks, Tiiu. 2010. "Ühtse Eesti suurkogu poliitikutele ei halastanud." Eesti Päevaleht 8 May.

Laks, Tiiu and Kaarel Kressa. 2010. "Ärge oodake kogu aeg uue partei tulekut." Eesti Päevaleht 10 May.

van Maanen, Hans. 2009. How to Study Art Worlds. On the Societal Functioning of Aesthetic Values. Amsterdam: Amsterdam University Press.

Mikomägi, Margus. 2014. "Igatsuse varjundite tundeküllus." Maaleht 5 June.

Niineste, Mart. 2011. "Kas me sellist Eestit tahtsimegi?" Eesti Päevaleht. 26 March.

Oidsalu, Meelis. 2011. "Euroopluse origami." Sirp. 7 October.

Prints, Kairi. 2009. "Kuidas seletada kunsti kehakultuuriministrile." Postimees. 12 March.

Purje, Pille-Riin. 2014. "Meil ei ole õnne ega tulegi ..." Sirp 19 June. 
Tõnson, Margit. 2010. "Kuidas ma allusin provokatsioonile." Eesti Ekspress 13 May.

Veidemann, Rein. 2009. "Armastuse antinoomiad." Postimees 14 December.

Veidemann, Rein. 2014. "Palavikuline Tšehhov." Postimees 4 June.

\section{AUTHOR}

Ott Karulin has a PhD in theatre studies from the University of Tartu (2013). In his dissertation he focused on the functioning of state-funded repertoire theatres in Estonia from 1985 onward. He is also an active theatre critic and is currently working as the editor-in-chief of an Estonian culture weekly paper Sirp. 